PRINT ISSN 1119-8362

Electronic ISSN 1119-8362
Full-text Available Online at https://www.ajol.info/index.php/jasem http://ww.bioline.org.br/ja
J. Appl. Sci. Environ. Manage.

Vol. 23 (8) 1497-1503 August 2019

\title{
Assessment of Natural Chelates to Enhance Zinc Biofortification in Cassava (Manihot esculenta Crantz)
}

\author{
*IKULI, JM; AKONYE, LA; EREMRENA, PO
}

Department of Plant Science and Biotechnology, University of Port Harcourt, PMB 5323 Choba, Port Harcourt, Rivers State, Nigeria

*Corresponding Author Email: ikulijosiah@yahoo.com

\begin{abstract}
The study examined the potentials of some organic chelates to enhance zinc availability, uptake and deposition in the edible root of cassava. The chelates used were EDTA as standard chelate, Bontera as commercial organic chelate and periwinkle effluents and Smoke solution as local organic chelates. The cultivars used were TME419 and TMS3168/UMUCASS/36 also known as YELLOW ROOT (YR). One hundred (100ml) of $100 \mu \mathrm{g}$ of zinc obtained from zinc oxide was added to $5000 \mathrm{ml}$ each of deionized water, $1 \mathrm{ml} / \mathrm{L}$ Bontera, $1 \mathrm{ml} / \mathrm{L}$ EDTA, Periwinkle effluents and Smoke solution. The treatments were applied through foliar application at 3 months after planting. The zinc concentration distribution ranged from $13.627 \mu \mathrm{g} / \mathrm{g}$ (YR peel; control) to $85.843 \mu \mathrm{g} / \mathrm{g}$ (YR edible root; EDTA +ZnO). In the edible root, the bioavailable zinc ranged from $18.494 \mu \mathrm{g} / \mathrm{g}$ (YR; Boontera+ $\mathrm{ZnO}$ ) to $85.843 \mu \mathrm{g} / \mathrm{g}$ (YR; EDTA $+\mathrm{ZnO}$ ). After processing to garri and fufu, the content ranged from $0.2116 \mathrm{mg} / 100 \mathrm{~g}$ (TME419; control) to $1.1645 \mathrm{mg} / 100 \mathrm{~g}(\mathrm{YR}$; Smoke solution $+\mathrm{ZnO}$ ) in fufu and $1.0178 \mathrm{mg} / 100 \mathrm{~g}(\mathrm{YR}$, Bontera $+\mathrm{ZnO})$ to $4.494 \mathrm{mg} / 100 \mathrm{~g}$ (TME419; PE $+\mathrm{ZnO}$ ) in garri. After seven months storage, TME419 retained $\mathrm{Zn}$ in $30 \%$ of the treatments, while YR retained $\mathrm{Zn}$ in $60 \%$ of the treatments. The study revealed that organic chelates have good potentials to enhance zinc biofortification. Periwinkle effluents proved to be better because it retains the nutrient for longer period after processing to garri. YELLOW ROOT proved to be better because it can retain zinc for a longer period. The use of organic chelates should be encouraged for micronutrients sufficiency, sustainable agriculture and food security.
\end{abstract}

DOI: https://dx.doi.org/10.4314/jasem.v23i8.13

Copyright: Copyright (C) 2019 Ikuli et al. This is an open access article distributed under the Creative Commons Attribution License (CCL), which permits unrestricted use, distribution, and reproduction in any medium, provided the original work is properly cited.

Dates: Received: 19 June 2019; Revised: 22 July 2019; Accepted 12 August 2019

Key words: Organic chelates, Zinc, Bioavailability, Cassava

Zinc ( $\mathrm{Zn})$ is an essential micronutrient, in that, it is needed in minute amount but its effects on the human body is astronomical. Zinc is among the micronutrients recognized by the World Health Organisation (WHO) as limited (Ortiz-Monasterior et al, 2007).Zinc deficiency influence about $1.9 \%$ of the total burden of diseases caused by major health risks worldwide (WHO, 2002; Hotz and Brown, 2004).It has been reported and proven that nutrients obtained from daily food is far more better than the same nutrients obtained from supplements and as such, increasing $\mathrm{Zn}$ availability through biofortification in food crops like cassava that is consumed by more than $90 \%$ population in Nigeria and over 2 billion people in the world will be a good strategy to combat $\mathrm{Zn}$ deficiency among people that consume cassava as a staple food crop. To make this nutrients sufficient for all, the most recommended tool is biofortification (Welch and Graham, 2000; Graham et al, 2001; Bouis et al, 2003; Graham, 2003; Genc et al, 2005; White and Broadley, 2005; White and Broadley, 2009; Ikuli et al, 2017). For effective achievement of biofortification as a strategy, the rural farmers who produce the bulk of the food consumed should be made the drivers of the strategy, by identifying natural sources of these nutrients many of which are lying waste among the people for easy application and effective utilization of the natural resources endowed to the environment. Cassava is an important component in the diets of over 190 million people in Nigeria today. Greater percent of its cultivation is by resource-poor families in the rural areas.Cassava is a dietary staple in much of the tropical Africa. Cassava is important because it provides about one fifth $(1 / 5)$ of the total calories human need among those that consume it. According to the USDA (2018), every $100 \mathrm{~g}$ of cassava root contains; $0.34 \mathrm{mg}(\mathrm{Zn})$.Cassava with its potential as a food security crop being cultivated and consumed by more than $90 \%$ of the Nigerian population and other part of the world, is in better position to be used in $\mathrm{Zn}$ biofortification in order to control the daily rising in chronic diseases cases related to $\mathrm{Zn}$ deficiency in the world especially Nigeria and Africa.

The objective of this research is to study the response of cassava and potentials of natural chelates to promote $\mathrm{Zn}$ availability in edible root via foliar application. 


\section{MATERIALS AND METHODS}

The study was carried out at University of Port Harcourt, Port Harcourt, Rivers state (Lat. 4 $54^{\prime} 31^{\prime \prime} \mathrm{N}$ and Long. $6^{\circ} 54^{\prime} 38^{\prime \prime} \mathrm{E}$ ). The temperature range from $23^{\circ} \mathrm{C}$ to $35^{\circ} \mathrm{C}$ and total rainfall range of $2000-3000 \mathrm{~mm}$ per anum, from November 2017 to November, 2018.

Planting Materials and Planting: Cassava cultivars were obtained from Faculty of Agricultural Teaching and Research Farm, University of Port Harcourt, namely; TME419 and TMS3168/UMUCASS/36 also known as Yellow Root. Cassava stems were cut into a length of $25 \mathrm{~cm}$ each and was planted $1 \mathrm{~m}$ by $1 \mathrm{~m}$.

Land Preparation and Plot Layout: A total land area of $522 \mathrm{~m}^{2}$ was cleared, ploughed and was partitioned into 30 plots. The plot size was $2 \mathrm{~m} \times 5 \mathrm{~m}$ with ten (10) treatments and three replicates. The distance inbetween treatment is $1 \mathrm{~m}$ and replicates $1.5 \mathrm{~m}$ apart. The randomized complete block design (RCBD) was used

Biofortification Material: Hydrochloric acid ( $\mathrm{HCl})$, Nitric acid, Zinc oxide $(\mathrm{ZnO})$ source of zinc and Ethylene diamine-tetra-acetic acid (EDTA) used as standard chelate were obtained from BENERCO Enterprise Alakahia, Port Harcourt, Rivers State, Nigeria.

Bontera; A microbial soil enhancer was obtained from Organico, A division of Amka Products in South Africa used as commercial organic chelate.

Periwinkle effluents were obtained from market women at Omuchiolu Aluu local market.

Smoke solution used as local organic chelate was locally prepared from dry wood particles

Preparation of Fortifying Solution: The zinc oxide $(\mathrm{ZnO})$ used as the zinc fertilizer was diluted to $100 \mu \mathrm{g}$ of zinc concentration fortifying solution was prepared in the following steps:

The glassware was treated with $\mathrm{HCl}$ to remove all traces of contaminants

Zinc oxide $(\mathrm{ZnO})$ weighing $6.23 \mathrm{~g}$ was dissolved in $20 \mathrm{ml}$ nitric acid, added deionized water to $1000 \mathrm{ml}$ level (solution A):

Five millilitres $(5 \mathrm{ml})$ of solution A was diluted in $1000 \mathrm{ml}$ of deionized water (solution B):

Ten millilitres $(10 \mathrm{ml})$ of solution $\mathrm{B}$ was diluted in $100 \mathrm{ml}$ of deionized water to give $1 \mathrm{ml}=100 \mu \mathrm{g}$ (solution C).
One hundred millilitres $(100 \mathrm{ml})$ of solution $\mathrm{C}$ was added to $5000 \mathrm{ml}$ each of deionized water, $1 \mathrm{ml} / 1$ Bontera, $1 \mathrm{ml} / \mathrm{L}$ EDTA, Periwinkle effluents and Smoke solution.

Biofortification Application: The prepared biofortifying solutions were applied through foliar application. The use of knap snack sprayer was employed for this purpose. The application was done at the early tuberization and bulking stage of the cassava plant development ( 3 months after planting), repeated after 3 weeks and repeated at the later bulking stage ( 7 months after planting).

Zinc Analysis: The leaves, stem and Root (flesh and peel) from each treatment were collected and analysed for bioavailable zinc content and other nutrients in the root.

The zinc content was determined using the Atomic Absorption Spectrophotometer (AAS) at a wavelength of $213.86 \mathrm{~nm}$.

SAS Software; One-way ANOVA and multiple comparism using LSD was used for the statistical analysis.

\section{RESULTS AND DISCUSSIONS}

Zinc content: The total Zinc concentration in the whole cassava plant ranged from $13.627 \mu \mathrm{g} / \mathrm{g}$ (YR Root peel; BT $+\mathrm{ZnO}$ ) to $85.843 \mu \mathrm{g} / \mathrm{g}$ (YELLOW ROOT Edible root; EDTA $+\mathrm{ZnO}$ ). In the edible root, the bioavailable $\mathrm{Zn}$ ranged from $18.494 \mu \mathrm{g} / \mathrm{g}$ (YELLOW ROOT; BT $+\mathrm{ZnO}$ ) to $85.843 \mu \mathrm{g} / \mathrm{g}$ (YELLOW ROOT; EDTA $+\mathrm{ZnO}$ ) as presented in table 1.

Zinc Mobility and Distribution in Cassava Plant: In control TME419, $16.42 \%$ of the total bioavailable zinc in the plant remained in the leaf, $25.07 \%$ in the stem, $33.69 \%$ in the edible root and $24.82 \%$ in the root peel. While in YELLOW ROOT control, 22.52\% was deposited in the leaf, $34.37 \%$ in the stem, $24.82 \%$ in the edible root and $18.29 \%$ in the root peel. For those treated with only zinc oxide ( $\mathrm{ZnO})$, in TME419; $17.045 \%$ was deposited in the leaf, $26.016 \%$ in the stem, $32.783 \%$ in the edible root and $24.156 \%$ in the root peel. While YELLOW ROOT treated with $\mathrm{ZnO}$ retained $10.696 \%$ in its leaf, $16.325 \%$ in stem, $42.018 \%$ in edible root and 30.961 in its root peel. For those treated with the chelates individually; TME419 treated with Bontera, deposited $12.652 \%$ in the leaf, $17.410 \%$ in stem, $39.173 \%$ in the edible root and $28.864 \%$ in the root peel. While YELLOW ROOT retained $20.412 \%$ in the leaf, $31.165 \%$ in the stem, $27.886 \%$ in the edible root and $20.547 \%$ in the root peel. For those treated with EDTA, TME419 
stored $18.37 \%$ in its leaf, $28.04 \%$ in stem, $30.86 \%$ in edible root and $22.73 \%$ in its root peel. While YELLOW ROOT stored $14.23 \%$ in leaf, $21.72 \%$ in stem, $36.88 \%$ in edible root and $27.18 \%$ in its root peel. In those that were treated with Periwinkle effluents, TME419 retained $25.1 \%$ of the total bioavailable zinc in its leaf, $38.31 \%$ in stem, $21.07 \%$ in edible root and $15.52 \%$ in root peel. While in YELLOW ROOT, $18.55 \%$ was in the leaf, $28.31 \%$ in the stem, $30.60 \%$ in the edible root and $22.54 \%$ in its root peel. Those treated with Smoke solution, TME419 had $9.91 \%$ deposited in its leaf, $15.14 \%$ in stem, $43.15 \%$ in edible root and $31.80 \%$ in its root peel. While YELLOW ROOT deposited $14.76 \%$ in its leaf, $22.52 \%$ in stem, $36.11 \%$ in edible root and $26.61 \%$ in root peel. For those that the chelates were applied in combination with zinc oxide; TME419 when treated with Bontera $+\mathrm{ZnO}$ had $15.45 \%$ in its leaf, $23.57 \%$ in the stem, $35.11 \%$ in the edible root and $25.87 \%$ in its root peel. While YELLOW ROOT had $29.17 \%$ in leaf, $44.53 \%$ in stem, $15.14 \%$ in edible root and $11.16 \%$ in root peel. Those treated with EDTA
$+\mathrm{ZnO}$; TME419 had19.37\% in its leaf, $29.56 \%$ in stem, $29.40 \%$ in edible root and $21.67 \%$ in root peel. While YELLOW ROOT had 19.29\% in leaf, 29.44\% in stem, $29.52 \%$ in edible root and $21.75 \%$ in the root peel. For those treated with PE $+\mathrm{ZnO}$; TME419 stored $19.22 \%$ of the total zinc in its leaf, $29.33 \%$ in stem, $29.62 \%$ in the edible root and $21.83 \%$ in the root peel. While in YELLOW ROOT, $15.45 \%$ was deposited in the leaf, $23.59 \%$ in the stem, $29.62 \%$ in the edible root and $25.86 \%$ in the root peel. For those treated with Smoke solution $+\mathrm{ZnO}$, TME419 retained $15.94 \%$ in the leaf, $24.33 \%$ in the stem, $34.39 \%$ in the edible root and $25.34 \%$ in the root peel. While YELLOW ROOT stored $14.86 \%$ in the leaf, $22.69 \%$ in the stem, $35.96 \%$ in the edible root and $26.49 \%$ in the root peel. In all the treatments, zinc was evenly distributed. This suggests that because of the vital role zinc plays in the metabolic activities in plant, its mobility was not restricted in anyway. And higher percentage in most of the treatments was deposited in the edible root as desired.

Table 1: Zinc $(\mu \mathrm{g} / \mathrm{g})$ Distribution in Cassava Plant

\begin{tabular}{|c|c|c|c|c|c|c|c|c|}
\hline \multicolumn{2}{|c|}{ TREATMENT } & \multicolumn{2}{|c|}{ TME 419 cultivar } & \multicolumn{4}{|c|}{ Yellow Root (YR) cultivar } & \multirow[b]{2}{*}{ Root peel } \\
\hline & Leaf & Stem & Root flesh & Root peel & Leaf & Stem & $\begin{array}{l}\text { Root } \\
\text { flesh }\end{array}$ & \\
\hline $\begin{array}{l}\text { Control } \\
\mathrm{ZnO}\end{array}$ & $\begin{array}{l}28.435 \\
36.177 \\
\end{array}$ & $\begin{array}{ll}5 & 43.401 \\
7 & 26.525 \\
\end{array}$ & $\begin{array}{l}58.329 \\
69.581 \\
\end{array}$ & $\begin{array}{l}42.977 \\
51.270 \\
\end{array}$ & $\begin{array}{l}39.192 \\
17.378 \\
\end{array}$ & $\begin{array}{r}59.819 \\
45.970 \\
\end{array}$ & $\begin{array}{l}43.200 \\
68.269 \\
\end{array}$ & $\begin{array}{l}31.831 \\
50.304 \\
\end{array}$ \\
\hline \multicolumn{9}{|c|}{ Chelates } \\
\hline EDTA & 38.373 & $\begin{array}{ll}3 & 58.570\end{array}$ & 64.453 & 47.492 & 22.352 & 34.116 & 57.941 & 42.694 \\
\hline BT & 19.279 & $9 \quad 29.422$ & 59.682 & 43.976 & 33.488 & 51.113 & 45.750 & 33.710 \\
\hline PE & 30.118 & $8 \quad 45.970$ & 25.276 & 18.624 & 42.459 & 64.805 & 70.021 & 51.595 \\
\hline SS & 16.259 & $9 \quad 24.811$ & 70.736 & 52.121 & 29.949 & 45.712 & 73.285 & 54.000 \\
\hline \multicolumn{9}{|c|}{ Chelates + Iodine Source } \\
\hline$\overline{\mathrm{BT}+\mathrm{Zna}}$ & 29.686 & $6 \quad 45.310$ & 67.486 & 49.726 & 35.638 & 54.395 & 18.494 & 13.627 \\
\hline $\mathrm{EDTA}+\mathrm{ZnOO}$ & 43.066 & $6 \quad 65.733$ & 65.377 & 48.173 & 56.076 & 85.589 & 85.843 & 63.253 \\
\hline $\mathbf{P E}+\mathrm{ZnQ} \mathbf{Q}$ & 42.882 & 265.452 & 66.094 & 48.701 & 31.337 & 47.829 & 71.175 & 52.445 \\
\hline $\mathrm{SS}+\mathrm{ZnO}$ & 33.977 & $7 \quad 51.860$ & 73.293 & 54.005 & 27.510 & 41.989 & 66.541 & 49.030 \\
\hline
\end{tabular}

NB: EDTA (Ethylene diamine tetra acetic acid); BT (Bontera); PE (Periwinkle Effluents); SS (Smoke Solution); ZnO (Zinc oxide)

In control TME419 had better accumulation efficiency, the potential to absorbed and deposit $\mathrm{Zn}$ in the edible root than YELLOW ROOT. TME419 still had higher accumulation efficiency than YELLOW ROOT when they were treated with $\mathrm{ZnO}$. When they were treated with Bontera, TME419 had higher accumulation efficiency. When they were treated with EDTA, TME419 still had better accumulation efficiency but when they were treated with Periwinkle effluents, YELLOW ROOT had higher accumulation efficiency. When they were treated with Smoke solution, YELLOW ROOT had higher accumulation efficiency. When the cultivars were treated with combinations of chelates and source, TME419 had higher accumulation efficiency when treated with; BT $+\mathrm{ZnO}$ and $\mathrm{SS}+\mathrm{ZnO}$, while YELLOW ROOT had higher accumulation efficiency when treated with $\mathrm{EDTA}+\mathrm{ZnO}$ and $\mathrm{PE}+\mathrm{ZnO}$. This suggests that $\mathrm{Zn}$ mobility is easier through the phloem and xylem of TME419 than passing through the phloem and xylem of YELLOW ROOT. The study also showed that all the chelates facilitated the mobility of $\mathrm{Zn}$ except Bontera when used in combination with $\mathrm{ZnO}$. Organic chelates enhance $\mathrm{Zn}$ mobility and accumulation in YELLOW ROOT than inorganic chelates.TME419 had flexible tissues that allow free mobility of substances and as such movement of nutrients applied through the leaves moved without restriction and accumulates in the root. And because of the weak or lack of chelating molecules in its tissues, it lacked the ability to retain the deposited nutrients in its tissues for a long period of time after being processed to garri except those chelated with Periwinkle effluents and Bontera as presented in table 3. Movement in yellow root was slower except with aid of organic chelates, because of its chelating potentials, YELLOW ROOT 
was able to store $\mathrm{Zn}$ that accumulated in its tissues for a longer period of time after processing to garri in those treated with $\mathrm{BT}, \mathrm{ZnO}, \mathrm{PE}, \mathrm{EDTA}+\mathrm{ZnO}, \mathrm{BT}+$ $\mathrm{ZnO}$ and even the untreated (control) as indicated in table 3 .

Potentials of Chelates in making nutrient available for Plant uptake and storage: Smoke solution had the highest influence in retaining $\mathrm{Zn}$ in the edible root in both cultivars when applied as single treatments, and was followed by $\mathrm{ZnO}$ in TME419 and Periwinkle effluents in YELLOW ROOT. When used in combination with $\mathrm{ZnO}$; in TME419; $\mathrm{SS}+\mathrm{ZnO}$ had the highest influence followed by $\mathrm{BT}+\mathrm{ZnO}$ and the least was EDTA + ZnO. While in YELLOW; EDTA + ZnO had the highest ability to deposit $\mathrm{Zn}$ in the edible root followed by $\mathrm{PE}+\mathrm{ZnO}$ and the least was $\mathrm{BT}+\mathrm{ZnO}$. There was significance difference at 5\% level of probability. Among the chelates, smoke solution seems to have the best capability to chelate $\mathrm{Zn}$ for cassava plant, but lacks the potential to store the $\mathrm{Zn}$ in processed cassava (garri) for long period of time like Bontera and Periwinkle effluents.

Bioavailable Issue: Because of the involvement and vitals roles $\mathrm{Zn}$ plays in plant metabolic activities in the whole plant growth, development and productivity, the amount of bioavailable $\mathrm{Zn}$ often deposited in the edible portion of the plant for human consumption is affected. However, biofortification helped to elevate this value. From the amount of bioavailable $\mathrm{Zn}$ after processing to $f u f u$ and garri, the amount retained in many treatments exceeded the Harvest Plus target for $\mathrm{Zn}$ availability. The bioavailable $\mathrm{Zn}$ in cassava processed to $f u f u$ ranged from $0.2116 \mathrm{mg} / 100 \mathrm{~g}$ (TME419; Control) to $1.164 \mathrm{mg} / 100 \mathrm{~g}$ (YELLOW ROOT; SS $+\mathrm{ZnO}$ ). These represent $2.116 \%$ of the average UK guidance reference nutrient intake (RNI) and $2.015 \%$ of the average US Recommended Daily Allowance (RDA) to $11.645 \%$ of the average UK RNI and $11.090 \%$ of the mean US RDA. In garri the bioavailable $\mathrm{Zn}$ ranged from $1.0178 \mathrm{mg} / 100 \mathrm{~g}$ (YELLOW ROOT; $\mathrm{BT}+\mathrm{ZnO}$ ) to $4.4941 \mathrm{mg} / 100 \mathrm{~g}$ (TME419; $\mathrm{PE}+\mathrm{ZnO})$ and these values represent $10.178 \%$ of the average UK RNI and $9.693 \%$ of the average US RDA to $44.941 \%$ of the average UK RNI and $42.801 \%$ of the average United State Recommended Daily Allowance. However, comparing these values to the USDA 1 Released April, 2018 which said that every $100 \mathrm{~g}$ of cassava contains $0.34 \mathrm{mg}$ of $\mathrm{Zn}$, the bioavailable $\mathrm{Zn}$ in both cultivars processed to garri in all the treatments were higher. When processed to fufu, $70 \%$ of the whole treatments in TME419 were higher, only 30\% (Control, PE and $\mathrm{EDTA}+\mathrm{ZnO})$ were lower and $100 \%$ treatments in YELLOW ROOT were higher than the USDA, 2018 value released. Fifty (50\%) of the treatments in TME419 (ZnO, Smoke solution, Smoke solution $+\mathrm{ZnO}$, Periwinkle extracts $+\mathrm{ZnO}$ and EDTA), when processed to garri exceeded the HarvestPlus Zn target for cassava which is $34 \mathrm{mg} / \mathrm{kg}(3.4 \mathrm{mg} / 100 \mathrm{~g})$

Zinc Biofortified Food Crops and Human Health: This study showed that illness and diseases induced by $\mathrm{Zn}$ deficiency in country like Nigeria and other countries that consume cassava as a staple can be brought to a halt. Consuming $\mathrm{Zn}$ biofortified cassava will help reduce the issue of infertility in both male and female. The male reproductive system need high amount of $\mathrm{Zn}$ to increase the testosterone levels and for the male prostate to perform optimally. The female reproductive system requires zinc for the growth of the oocyte (egg) (Poliquin, 2012). Inadequate $\mathrm{Zn}$ causes premature egg and ovulation impeded in female and low sperm count in male. Tumour growth infection is on the increase on daily basis; tumour results from inability of damaged prostate cells to accumulate zinc and thus enhance growth of cancer cells. Biofortifying cassava with $\mathrm{Zn}$ will eliminate this menace in Nigeria since it is a major consumed staple. Research has proved that many $\mathrm{Zn}$ supplements contain cadmium (Cd), and high amount or frequent intake of cadmium (Cd) causes kidney failure. Consuming Zn biofortified cassava frees the populace from the risk of kidney failure resulting from consumption of $\mathrm{Zn}$ supplements. Zinc fights cancerous cells (Poliquin, 2012; Nordqvist, 2017); and consuming $\mathrm{Zn}$ biofortified cassava will help to reduce cancer disease; a disease that no proper treatment solution has been achieved. Zinc bofortified cassava will eradicate diabetes in the society. Zinc helps insulin to function efficiently in converting blood sugar to energy and other metabolic activities. Zinc help to maintain the health of cardiovascular cells and endothelium for efficient elimination of cholesterol and inflammation, and reduce the risk of heart diseases (Poliquin, 2012; Nordqvist, 2017). Because of the antioxidant property of zinc, consuming Zn biofortied cassava, will help neutralize free radical bonding to what we consume that are inside the body that can cause damage to the body system and also remove heavy metals from the brain to avoid building up in the tissue to cause damage (Poliquin, 2012). Biofortifying cassava with $\mathrm{Zn}$ will eradicate stunting in the society. Biofortifying cassava with $\mathrm{Zn}$ will produce citizens with strong immune systems, because $\mathrm{Zn}$ is essential for growth. This will also help in age related ill health and muscular problems. Zinc is necessary for the synthesis of DNA and is also needed for fast healing of wounds. Biofortifying cassava with $\mathrm{Zn}$ in Nigeria will make $\mathrm{Zn}$ availability sufficient for greater percentage of the populace. 
Table 2: Zinc (mg/100g) Content In Processed Cassava

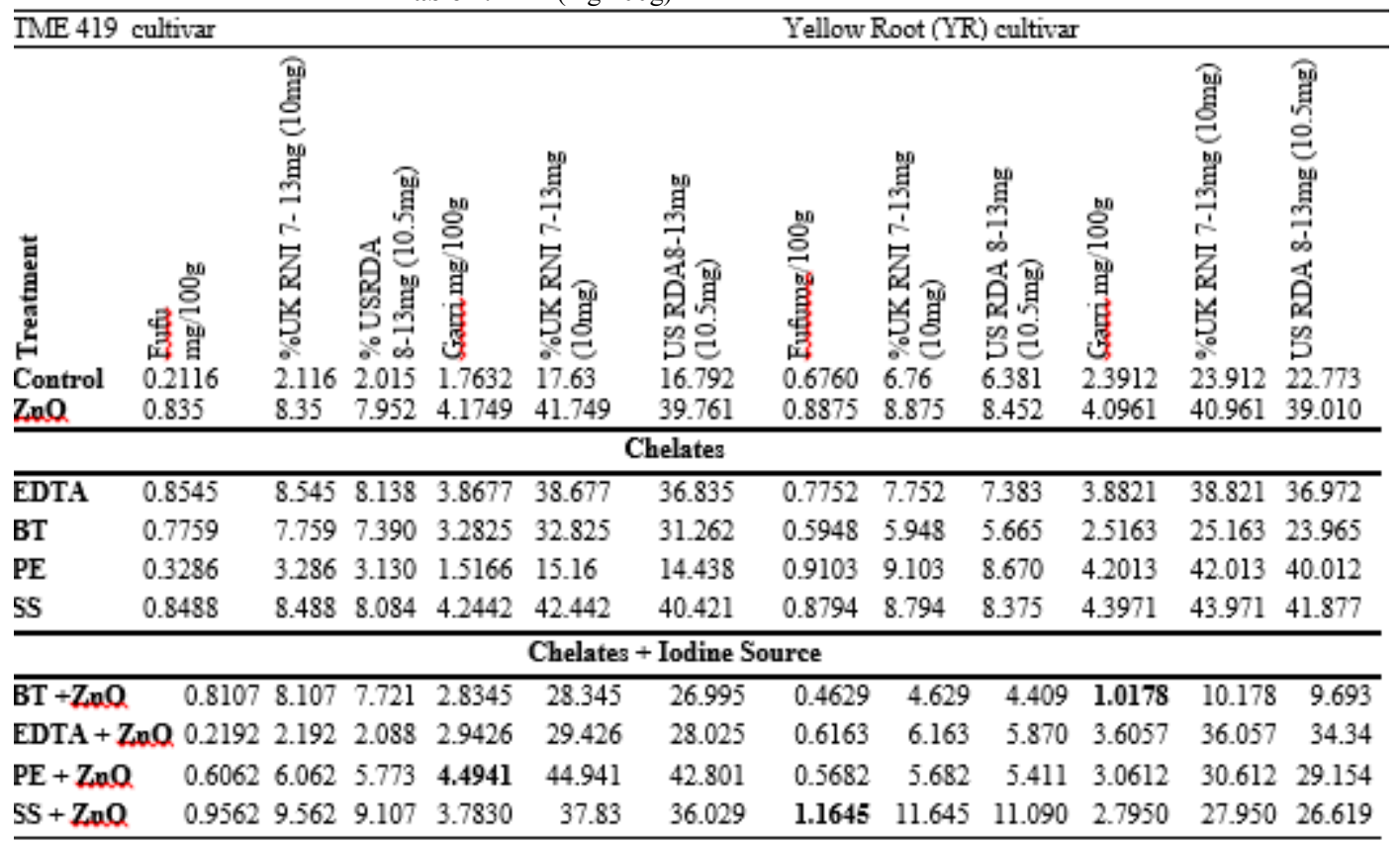

NB: EDTA (Ethylene diamine tetra acetic acid); BT (Bontera); PE (Periwinkle Effluents); SS (Smoke Solution); ZnO (Zinc oxide); US RDA (United State Recommended Daily Allowance); UK RNI (United Kingdom, Reference nutrient intake). In YELLOW ROOT, the bioavailable Zn after processed to garri $50 \%(\mathrm{ZnO}$, EDTA, PE, EDTA $+\mathrm{ZnO}$ and Smoke solution) of all the treatments exceeded the Harvest Plus target for zinc in cassava.

Table 3: Zinc $(\mathrm{mg} / 100 \mathrm{~g})$ content in processed cassava after 7 months storage

\begin{tabular}{lll}
\hline T rentment & $\begin{array}{l}\text { TME 419 } \\
\text { cvltivar }\end{array}$ & $\begin{array}{l}\text { Yellow Root (YR) } \\
\text { cultivar }\end{array}$ \\
\hline \multicolumn{3}{c}{ Garri } \\
CONTROL $/ 100 \mathrm{~g}$ & $\begin{array}{l}\text { Garri } \\
\mathrm{mg} / 100 \mathrm{~g}\end{array}$ \\
ZnO & 0.000 & 0.283 \\
\hline \multicolumn{3}{c}{ CHELATE S } \\
\hline E DTA & 0.000 & 0.130 \\
BT & 0.054 & 0.000 \\
PE & 0.001 & 0.005 \\
SS & 0.000 & 0.013 \\
& 0.000 \\
\hline \multicolumn{3}{c}{} \\
\hline BT +ZnO & 0.000 & 0.683 \\
E DT A + ZnO & 0.000 & 0.199 \\
PE + ZnO & 0.334 & 0.000 \\
SS +ZnO & 0.000 & 0.000 \\
\hline
\end{tabular}

NB: EDTA (Ethylene diamine tetra acetic acid); BT (Bontera); PE (Periwinkle Effluents); SS (Smoke Solution); ZnO (Zinc oxide);

Organic Chelate Biofortification and Food Security: The use of natural sources of nutrients in biofortification frees the soil and environment from pollutants and contaminants often introduced by inorganic sources of nutrients that are not utilized by the plant. These natural chelates are rich in many essential macro and micro nutrients needed by plant and nutrients that have chelating properties like sodium (Na). For example, every one litre of periwinkle effluents contains; $153.13 \mathrm{mg}(\mathrm{K})$, 55.30mg(Ca), 207.50mg(Mg), $\quad 9.09 \mathrm{mg}(\mathrm{P})$, 193.75mg( $\mathrm{Na}), \quad 2.18 \mathrm{mg}(\mathrm{I}), \quad 12.80 \mathrm{mg}\left(\mathrm{NO}_{3}\right)$, $0.61 \mathrm{mg}(\mathrm{Zn}), 0.9 \mathrm{mg}(\mathrm{Cu}), 0.2 \mathrm{mg}(\mathrm{Mn})$ and $1.90 \mathrm{mg}(\mathrm{Fe})$ with a $\mathrm{pH}$ of 6.5 which favours the absorption of all nutrients. In every one litre of Smoke solution you have; $0.63 \mathrm{mg} \quad(\mathrm{K}), \quad 1.43 \mathrm{mg}(\mathrm{Ca}), \quad 0.42 \mathrm{mg}(\mathrm{Mg})$, $2.18 \mathrm{mg}\left(\mathrm{NO}_{3}\right), 1.63 \mathrm{mg}(\mathrm{Na}), 14.70 \mathrm{mg}(\mathrm{P}), 1.38 \mathrm{mg}(\mathrm{Fe})$, $0.08 \mathrm{mg}(\mathrm{Cu})$ and $0.28 \mathrm{mg}(\mathrm{Zn})$ or more depending on quantity of dry wood particles used with a $\mathrm{pH}$ of 5.36 which is optimal for all nutrients absorption. In every $2 \mathrm{ml} / 1$ of Bontera (microbial soil enhancer) a commercial organic chelate; $267.25 \mathrm{mg}(\mathrm{P}), 19 \mathrm{mg}(\mathrm{K})$, 
$3.49 \mathrm{mg}\left(\mathrm{NO}_{3}\right) \quad 3 \mathrm{mg}(\mathrm{Ca}), \quad 0.81 \mathrm{mg}(\mathrm{Mg}), \quad 7.51 \mathrm{mg}(\mathrm{Na})$, $1.47 \mathrm{mg}(\mathrm{Fe}), 0.4 \mathrm{mg}(\mathrm{Zn}), 0.08 \mathrm{mg}(\mathrm{Cu})$ and $1.02 \mathrm{mg}(\mathrm{I})$ with $\mathrm{pH}$ of 6.71 , which is good for many nutrients and optimal for all in high acidic soil. They all have good chelating agents that bond nutrients and make them available for plant uptake and this will increase productivity. When organic chelates and inorganic sources were applied individually, including a universal standard inorganic chelate (EDTA),Smoke solution influenced $\mathrm{Zn}$ bioavailability these more than other sources in both cultivars. When used in combination with $\mathrm{ZnO}$, it was still the second to the highest. After processing cassava to fufu and garri, local organic chelates still retained the highest amount of $\mathrm{Zn}$ (Smoke solution $+\mathrm{ZnO}$ in $f u f u$ and Periwinkle effluents $+\mathrm{ZnO}$ in garri). Among the chelates used, Periwinkle effluent was the best because; it helps to store nutrients for longer time and was stable when used on both cultivars in combination with $\mathrm{ZnO}$. In general, all the organic chelates used have good potentials in making micronutrients available for food crop. This has proved the organic chelates to be better, because they are environmental friendly, cost effective and easy application by all farmers. They also enhanced nutrients storage in food for a longer period and renew vigor of planting materials. Among the cultivars used, YELLOW ROOT has the best ability to retain micronutrients after being processed to either $f u f u$ or garri for a longer period. The method of processing and the end product in which cassava is processed also determine the level of bioavailability of Zn.

Zinc biofortification and Availability of Planting Material in Cassava: Zinc ( $\mathrm{Zn}$ ) is involved in many enzymatic activities. Zinc is vital in the synthesis of tryptophan, a component of some proteins compound needed for the production of growth hormones, particularly auxin like Indole Acetic Acid (IAA) (Havlin et al, 2006). In plants $\mathrm{Zn}$ is used in chlorophyll formation, carbohydrate and conversion of starch to sugar. It helps plants to build cold/frost resistance immune. Biofortifying cassava with zinc provides sufficient zinc for all these metabolic activities. The ability of $\mathrm{Zn}$ to generate auxin prolongs the shell-life of the cassava planting material. This helps to delay senescence in cassava plant and enhance yield and makes more stems available for reproduction. The vigour of planting materials is renewed yearly after every $\mathrm{Zn}$ biofortification exercise and this enhance productivity.

Conclusion: To build a healthy society free of chronic diseases with food security, rural farmers who produce the bulk of food consumed should be the drivers of biofortification to conquer malnutrition. The use of organic chelates should also be encouraged by proper orientation of natural resources abound in our environment for judicious utilization of the potentials of what is lying waste in the environment. And this will enhance clean and healthy environment, production of healthy, nutritious and longer shelf-life food products for better food security and healthy society.

\section{REFERENCES}

Bouis, H E; Chassy, BM.; Ochanda, O (2003).Genetically modified food crops and their contribution to human health and food quality. Trends in Food Sci. Technol. 4: 191- 209

Department of Health (UK) (1991). Report on Health and Social Subjects 41. Dietary Reference Values for Food Energy and Nutrients. London: HMSO; doi: 10.1046rj.1365 313X.2002.01467.x.

Genc, Y; Humphries, J M; Lyons, GH; Graham, R D (2005). Exploiting genotypic variation in plant nutrient accumulation to alleviate micronutrient deficiency in populations. J. Trace Elements in Med. Biol. 18: 319- 324

Graham, RD (2003). Biofortification: A global challenge program. International Rice Research Notes (IRRN) 28.1:4- 8

Graham, R D; Welch, R M; Bouis, H E (2001). Addressing micronutrient malnutrition through enhancing the nutritional quality of staple foods: principles, perspectives and knowledge gaps. $A d v$. Agron. 70, 77-142.

Havlin, J L; Beaton, JD; Tisdale, SL; Nelson, W L (2006). Soil Fertility and Fertilizers. Asoke K. Ghosh, Prentice-Hall of India Private Limited, M97, Connaught Circus New Delhi- 110001. $7^{\text {th }}$ edition: 254- 411 .

Hotz, C; Brown, K H (2004). International Zinc Nutrition Consultative Group. Technical Document \#1 Assessment of the risk of Zinc deficiency in populations and options for its control. Food Nutrition. Bull. 25, 591-5203.

Ikuli, J M; Akonye, LA; Efisue, A. A. (2017).Comparative Study of some Cultivars of Rice (Oryza sativa L.) for Iron Fe Biofortification under Saline Condition. Greener J. Agric. Sci. 7(4): $105-111$.

Institute of Medicine (USA) (2001).Dietary Reference Intakes for Vitamin A, Vitamin K, (Arsenic), 
Boron, Chromium, Copper, Iodine, Iron, Manganese, Molybdenum, Nickel, Silicon, Vanadium and Zinc. Washington, DC: National Academics Press.

Ortiz-Monasterior, I J; Palacios-Rojas, N; Meng, E; Pixley, K; Trethrowan, R; Pena, R J (2007).Enhancing the mineral and vitamin content of wheat and Maize through plant breeding. Journal of Cereal Science, 46:293-307.

Nordqvist, J. (2017). What are the Health benefits of Zinc? MEDICAL NEWS TODAY. Www.google.com Retrieved December, 2017.

Pfeiffer, W H; McClaflerty, B (2007). Harvest Plus: breeding crops for better nutrition. Crop Sci. 47, 588-5105

Poliquin Group (2012). Top Ten Benefits of Zinc. http://www.google.com. Retrieved December, 2017.

Statistical Analysis System (SAS) (2012), SPSS Version 21.
United States Department of Agriculture, Agricultural Research Services, National Nutrient Database for Standard Reference.1 Release. April, 2018. Retrieved November, 2018

Welch, R M; Graham, RD (2000). A new paradigm for world agriculture: productive, sustainable, nutritious, healthful food systems. Food Nutrition Bull. 21: $361-366$.

World Health Organization (WHO) (2002). The World Health Report 2002. Geneva: World Health Organization

White, P J; Broadley, M R (2005). Biofortifying crops with essential mineral elements. Trends Plant Science. 10, 586-593.

White, P J; Broadley, M R (2009). Biofortification of crops with seven mineral elements often lacking in human diets-iron, zinc, copper, calcium, magnesium, selenium and iodine. New Physiologist. 182, 49-84. 